\title{
Dış Ticaretin Bölgesel Rekabetteki Yeri: Sivas Örneği
}

\author{
The Place Of Foreign Trade In Regional Competttıon: The Case of Sivas
}

\author{
Nevzat BALIKÇIOĞLU*
}

\begin{abstract}
$\ddot{O} Z$
Bu çalışmada 2006-2016 dönemi dikkate alınarak Orta Anadolu'nun önemli illerinden biri olan Sivas'ın dļs ticareti analiz edilmiştir. Analiz sonuçlarına göre, Sivas Orta Anadolu'da 48 ürün ve 76 ülkeye yaptı̆ğ ihracatla bölgede dördüncü sirada yer alırken ülke genelinde ihracatta 61.sirasında bulunmaktadır. Sivas Organize Sanayi Bölgesi'nde 2006 yllında 48 olan ihracatçı firma saylsı 2016 yllında 60'a ulaşmıştır. Benzer şsekilde 2016 yllında 49 ürün ithal eden Sivas'ta ithalatçı firma saylsı 2006'da 47 iken bu sayı 2016 yllında 79'a yükselmiştir. 2016 yllında toplam ihracat 80.161, toplam ithalat 69.673 milyon dolar olarak gerçekleşmiştir. Imalat Sanayi Sivas sanayisinin önemli sektörlerinden birisidir. Bu sektörden 2016 yll itibariyle 53 ülkeye 52.1 milyon dolarlık ihracat gerçekleştirilmişstir. Bu sektörü 26.3 milyon dolar ihracatla Madencilik ve Taş Ocakçılığ Sektörü takip etmiştir. Sivas'ın 2016 yllındaki toplam 69.673 milyon dolarlık ithalatının ilk sırasın 54 milyon dolar ile Toptan ve Perakende Ticaret Sektörü oluşsurmuştur. Sivas'ın dış ticaret bilançosu incelendiğinde, 2006, 2007,2009, 2010, 2011 ve 2013 ylllarında açık verdiği ve Orta Anadolu'da rekabet gücünün düşük olduğ görülmüsstür.
\end{abstract}

\section{ANAHTAR KELIMELER}

TR 7, Orta Anadolu Bölgesi, Dış Ticaret, Ihracat, İthalat

\begin{abstract}
In this study, foreign trade of Sivas, one of the important cities of Central Anatolia, was analyzed by considering 20062016 period. According to the results of the analysis, while Sivas is in the fourth place in the Central Anatolia region with 48 products and 76 countries that it exports, it is in the 61st place with regard to exports throughout the country. The number of exporters in Sivas Organized Industrial Zone which was 48 in 2006 reached 60 in 2016. Similarly, the number of importing companies in Sivas, which imported 49 products in 2006, increased from 47 to 79 in 2016. In 2016, total exports amounted to $\$ 80,161$ million and total imports amounted to $\$ 69,673$ million. Manufacturing Industry is the most important sector of Sivas industry. As of 2016, this sector has exported various products to 53 countries and the exports in 2016 reached 52.1 million dollars. This sector is followed by Mining and Quarrying Sector with 26.3 million-dollar export. The Wholesale and Retail Trade Sector with \$ 54 million takes the first place of Sivas's total imports of \$ 69.673 million in 2016. When the foreign trade balance of Sivas is examined, it is seen that it gives deficit in 2006, 2007, 2009, 2010, 2011 and 2013 and its competitive power is low in Central Anatolia.
\end{abstract}

KEYWORDS

TR 7 Central Anatolia Region, Foreign Trade, Exports, Imports

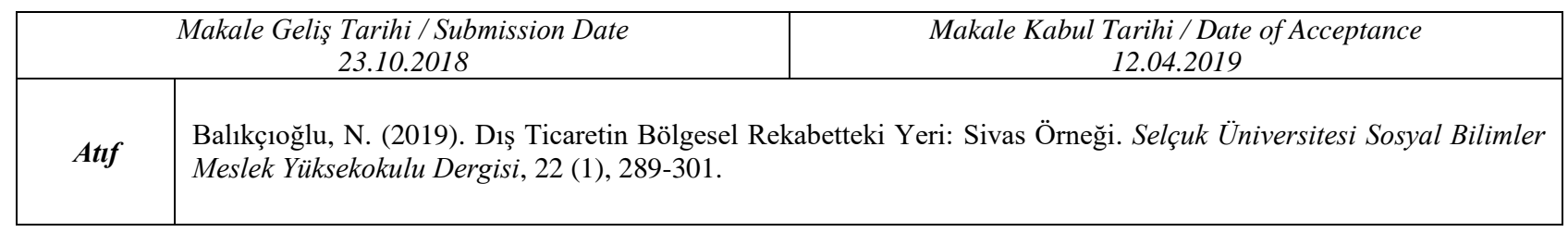

\footnotetext{
* Dr. Öğretim Üyesi,, Cumhuriyet Üniversitesi İktisadi ve İdari Bilimler Fakültesi, İktisat Bölümü, Sivas, balikcioglu@cumhuriyet.edu.tr, ORCID: 0000-0002-8642-9013
} 


\section{GİRIŞ}

Ekonomik büyüme, uygulanan iktisadi politikaların başarısını gösteren en önemli çıktılar arasında yer almaktadır. Ekonomik büyümenin uzun dönemde durağan duruma geleceğini öngören Neoklasik Büyüme Modelleri, 1970'ler ile 1980'lerde yaşanan ekonomik durgunluğu açıklayamamıştır. Bununla birlikte bahsedilen dönemde Keynesyen toplam talep ve devlet müdahalelerine dayalı ekonomi politikalarının güvenilirliği sarsılmış ve neticede ortaya çıkan yeni arayışlar, 1980'li yılların başında içsel büyüme teorilerinin gelişmesine neden olmuştur. Yeni büyüme modellerinde, büyümenin dışsal güçler yerine ekonomik sistemin içsel güçlerinin bir sonucu olduğu üzerinde durulmaktadır. İçsel büyüme teorisi, teknolojik büyümenin üretim ve yatırımın bir yan ürünü olduğunu kabul etmektedir. Teknolojik sorunlar önemsenmekte, üreterek öğrenme, beşeri sermaye birikimi gibi boyutlar dikkate alınmaktadır (Güvel, 2011: 111-112). İ̧sel büyüme modellerinde dış ticaret teknolojik gelişmeye ve ekonomik büyümeye katkı yapan bir faaliyet olarak görülmektedir.

Ekonomik kalkınmaya dış ticaret iki yönde katkı sağlamaktadır. Birincisi, dış ticaret bilgi akışı yoluyla uluslararası piyasalarla olan ilişkileri geliştirmekte ve bu şekilde ortaya çıkan yayılma ekonomik büyümeyi olumlu yönde etkilemektedir. Dış ticareti olumsuz etkileyen koruma araçlarının yarattığı daraltıcı etkiler ise, bu yayılmalar nedeniyle telafi edilebilmektedir. Diğeri ise dış ticaretin ulusal AR-GE'yi özendirici bir fonksiyona sahip olmasıdır (Kuşat, 2005: 89-90, Saçık, 2009: 41, Türker, 2009: 90-9).

Literatürde yer alan çalışmalarda ağırlıklı olarak dış ticaretin ihracat boyutuna ve ihracatın bölgesel rekabet ve ekonomik kalkınma üzerindeki etkisine odaklandığı görülmektedir (Shaw (1992), Ghatak ve Utkulu (1995), Yousıf (1997), Ekanayake (1999), Ghirmay vd. (2001), Çoban (2003), Utkulu ve Özdemir (2004), Demirhan (2005), Çoban vd. (2016). Bu çalışmalar kapsamında genel görüş, dış ticaretin bölgesel rekabeti artırdığı ve ekonomik kalkınmayı hızlandırdığı yönündedir. Küreselleşme ile birlikte bölgesel rekabet ve kalkınma konusunda ihracatın önemi her geçen gün daha da artmaktadır. Türkiye'de ihracat hacminin ekonomik kalkınmaya uzun dönemli ve pozitif katkı yaptığı ve bunun içsel büyüme teorisini doğruladığı görülmüştür.

$\mathrm{Bu}$ çalışmada bölgesel rekabet açısından Sivas'ın rekabet potansiyeli ve bölgesel rekabet gücü ele alınmıştır. Sivas, geçmiş dönemlerde de önemli ticaret merkezlerinden birisidir. Bu kapsamda hüküm süren uygarlıkların Sebaste, Sipas, Megalopolis, Kabira, Diaspolis (Tanrı Şehri), Talaurs, Danişment İli, Eyalet-i Rum, Eyalet-i Sivas gibi isimlerle andığı Sivas ili tarihinin, arkeolojik kazıların ışığında ortaya çıkan verilere göre neolitik döneme (MÖ 8000 - 5000) kadar uzandığı bilinmektedir. Tarihi İpekyolu'nun üzerinde bulunan Sivas'ta Hitit uygarlığının ardından Frigyalılar, Lidyalılar, Medler, Persler, Makedonlar, Romalılar, Danişmentliler, Selçuklular ve Osmanlılar hâkimiyet kuran diğer devletler olarak karşımıza çıkmaktadır. Sivas, Osmanlı döneminde; Amasya, Çorum, Tokat, Malatya'nın bir kısmı ve Kayseri illerinin kendisine bağlandığı bir eyalet merkezi haline getirilmiştir (ORAN Sivas Yatırım Rehberi, 2017: 4-5). Hali hazırda $27.202 \mathrm{~km}^{2}$ 'lik yüzölçümüyle bu anlamda Türkiye'nin ikinci en büyük ili konumundaki Sivas Doğu Anadolu, Karadeniz ve Akdeniz bölgeleriyle komşu durumdadır. 16 ilçesi bulunan Sivas'ın 2016 yılı verilerine göre nüfusu 623.224 kişi olup nüfusu en yüksek iller arasında 32. Sırada bulunmaktadır (ORAN Sivas Yatırım Rehberi, 2017: 4-5).

Sivas sanayi alanındaki sektörler ağırlıklı olarak küçük ve orta ölçekte olmakla birlikte, mevcut yatırımlar açısından incelendiğinde geniş bir çeşitliliğe sahip olduğu ve belli başlı sektörlerin ön plana çıktığ1 görülmektedir. Bu açıdan bakıldığında gıda ürünleri imalatı, madencilik ve taş ocakçılığı, mineral ürün imalatı, mobilya imalatı, metal cevheri madenciliği, giyim eşyası imalatı gibi alanlar şehrin en önemli sektörleri olarak karşımıza çıkmaktadır. Sahip olduğu yeraltı zenginlikleri nedeniyle madencilik sektörünün yoğun olduğu Sivas, yeni maden yatakların tespit edilmesi ve bu kaynakların yüksek katma değerli ürüne dönüştürülebilmesi bakımından önemli bir potansiyele sahiptir.(ORAN, 2017: 7).

Bu çalışmanın amacı, Sivas'ın dış ticaretinin Orta Anadolu bölgesindeki diğer şehirlerle karşılaştırmalı olarak analiz edilmesidir. Analizlerde 2006-2016 dönemine ilişkin veriler kullanılmış olup, söz konusu veriler T.C Ekonomi Bakanlığı, Türkiye İstatistik Kurumu (TÜIK), Sivas Ticaret ve Sanayi Odası (STO), Sivas Organize Sanayi Müdürlüğü, Orta Anadolu Kalkınma Ajansı'nın (ORAN) veri tabanlarından faydalanılmıştır.

\section{LITERATÜR}

Literatürde yer alan çalışmalarda ağırlıklı olarak dış ticaretin ihracat boyutuna ve ihracatın bölgesel rekabet ve ekonomik kalkınma üzerindeki etkisine odaklandığı görülmektedir (Shaw (1992), Ghatak ve Utkulu (1995), Yousıf (1997), Ekanayake (1999), Ghirmay vd. (2001), Çoban (2003), Utkulu ve Özdemir (2004), Demirhan (2005), Çoban vd. (2016). Bu çalışmalar kapsamında genel görüş, dış ticaretin bölgesel rekabeti artırdığı ve ekonomik kalkınmayı hızlandırdığı yönündedir. Küreselleşme ile birlikte bölgesel rekabet ve kalkınma konusunda ihracatın önemi her geçen gün daha da artmaktadır. Türkiye'de ihracat hacminin ekonomik kalkınmaya uzun dönemli ve pozitif katkı yaptığı ve bunun içsel büyüme teorisini doğruladığı görülmüştür. 
Mallick (1994), Bahmani-Oskooee ve Domac (1995), Thornton (1996), Ramos (2001) ihracattan ekonomik büyümeye doğru bir nedensellik olduğunu ortaya koyan çalışmalardan bazılarıdır.

Mallick (1994) Hindistan için yaptığı çalışmada, kısa ve uzun dönemde ihracattan büyümeye doğru nedensellik ilişkilerini ortaya koymuştur.

Bahmani-Oskooee ve Domac (1995), 1923-1990 dönemini kapsayan, eşbütünleşme ve hata düzeltme modelinin kullanıldığı çalışmalarında, ihracatla ekonomik büyüme arasında uzun dönemli bir ilişkinin mevcut olduğunu tespit etmişlerdir.

Ramos (2001) çalışması Portekiz ekonomisi için Johansen eştümleşme ve hata düzeltme modeline dayalı Granger nedensellik analizleri çerçevesinde yürütülmüştür. Sınama sonuçları ihracat artışı ve ekonomik büyüme arasında eştümleşme, uzun ve kısa dönem çift yönlü nedensellik ilişkilerinin var olduğunu göstermektedir.

Bu konuda Türkiye için de bazı çalışmalar yapılmıştır. Kösekahyaoğlu ve Şentürk (2006), ihracata dayalı büyüme hipotezinin geçerli olup olmadığını Granger nedensellik yöntemi ile incelemiştir. Nedensellik sınaması sonuçlarına göre, araştırmaya konu olan ülkelerden Türkiye, Çek Cumhuriyeti, Macaristan, Polonya, Hindistan ve Çin için ise ihracattan büyümeye doğru tek yönlü nedensellik ilişkisi bulunmuştur.

Yapraklı (2007) Türkiye'de ekonomik büyüme ve ihracat arasındaki nedensellik ilişkisini araştırdığı çalışmasının sonucunda, ekonomik büyüme ile ihracat arasında oldukça kuvvetli bir ilişkinin olduğu sonucuna ulaşmıştır.

Bilgin ve Şahbaz (2009) 1980'li yılların ikinci yarısından sonrasındaki Türkiye'nin dış ticaretinin gelişmesinde ihracat ve ekonomik büyüme arasında nedensellik ilişkisini inceledikleri çalışmalarında, ihracata yönelik değişmelerin ekonomik büyümeyi etkilemesi nedeniyle, büyümenin artırılabilmesi için ihracatın teşvik edilmesi gerektiğini tespit etmişlerdir.

Halıcıoğlu (2007), ise çalışmasında Türkiye için ihracat ve sanayi üretimi ilişkisini incelemiş ve sınama sonuçlarına göre ihracattan sanayi üretimine doğru tek yönlü nedensellik ilişkisini ortaya koymuştur.

Şimşek ve Kadılar (2010) 1960-2004 döneminde uzun dönemde ortaya çıkan sermaye birikimi ve ihracattaki artışın uzun dönemde GSMH üzerinde pozitif etki yaptığı sonucuna ulaşmışlardır.

\section{VERİ SETI VE YÖNTEM}

Günümüzde OSB'ler (Organize Sanayi Bölgeleri), bölgesel rekabetin il düzeyinde en önemli aracıdırlar. 19. Yüzyılın sonlarında sanayilerin belirli bir plan dâhilinde yerleştirilmesi ve geliştirilmesinin önemine bağlı olarak dünyada ilk örneğinin İngiltere'de görüldüğü bu uygulamaya 20. Yüzyılın başlarında Amerika Birleşik Devletleri ve diğer gelişmiş ülkelerde önem vermeye başlamışlardır. Türkiye'de ise ilk OSB 1962 yılında Bursa'da faaliyete geçirilmiştir. Sivas I. Organize Sanayi Bölgesi, Bakanlar Kurulu'nun 15.07.1976 tarih ve 7/12207 sayılı kararnamesiyle kurulmuştur. 22.04.2015 tarihinde ise imar planları yapımı tamamlanarak Sivas II. OSB'de faaliyetlerin başlatılması ve yatırım programına alınması için Bilim, Sanayi ve Teknoloji Bakanlığı'ndan talepte bulunulmuştur.

Bu kapsamda çalışmamızda T.C Ekonomi Bakanlığı, Türkiye İstatistik Kurumu (TÜIK), Sivas Ticaret ve Sanayi Odası (STO), Sivas Organize Sanayi Müdürlügü, Orta Anadolu Kalkınma Ajansı'nın (ORAN) veri tabanlarından elde edilen 2006-2016 dönemine ilişkin veriler kullanılmıştır.

Analizler, ihracat ve ithalat analizleri başlıkları altında yapılmıştır. Bu kapsamda Sivas OSB'de faaliyet gösteren firmaların sektörel dağılımı, ihracatçı firma sayısı ve ihracat değeri, ihracatın sektörel dağılımı, en fazla ihracat yapılan ilk 10 ülke, Sivas ve Orta Anadolu illerinin ihracatlarının gelişimi ve Sivas'ın ülke ihracatındaki payı gibi göstergelerden yararlanılmıştır. Benzer analiz süreci ithalat açısından da dikkate alınmıştır. Bu analizler doğrultusunda dış ticaret dengesi incelenmiştir.

\section{ANALIZ SONUÇLARI}

Sivas'taki OSB'de faaliyet gösteren firmaların sayıları ve sektörel dağılımı Tablo-1'de gösterilmiştir. 
Tablo- 1: Sivas OSB'nde Faaliyet Gösteren Firmaların Sektörel Dağılımı

\begin{tabular}{|l|l|l|}
\hline SIRA & SEKTÖR ADI & FİRMA SAYISI \\
\hline 1 & Gida Ürünleri İmalatı & 25 \\
\hline 2 & Giyim Eşyalarının İmalatı & 10 \\
\hline 3 & Ağaç, Ağaç Ür. ve Mantar Üretim İmalatı & 21 \\
\hline 4 & Kimyasalların ve Kimyasal Ürün İmalatı & 6 \\
\hline 5 & Temel Eczacılık Ür. ve Eczacııı̆a İlişkin Malzeme İmalatı & 3 \\
\hline 6 & Kauçuk ve Plastik Ürünlerinin İmalatı & 14 \\
\hline 7 & Diğer Metalik Olmayan Mineral Ürünlerin İmalatı & 12 \\
\hline 8 & Ana Metal Sanayi & 2 \\
\hline 9 & Fabrikasyon Metal Ürünleri İmalatı & 28 \\
\hline 10 & Bilgisayarların, Elektronik ve Optik Ürünlerin İmalatı & 1 \\
\hline 11 & Diğer İmalatlar & 23 \\
\hline TOPLAM & 155 \\
\hline
\end{tabular}

Kaynak: Sivas OSB, 2017.

Tablo-1'e göre Sivas OSB'de toplam 155 firma bulunmaktadır. Sektörel açıdan bakıldığında firmaların \%18'i Fabrikasyon Metal Ürünleri İmalatı Sanayi'nde faaliyet gösterdiği tespit edilmiştir. Bu sektörü \%14'lük pay ile Diğer İmalatlar, \%13.5 payla Ağaç, Ağaç Ürünleri ve Mantar Üretim İmalatı Sanayi ve \%9 pay ile Kauçuk ve Plastik Ürünlerinin İmalatı takip etmektedir.

\section{1. İhracat Analizi}

Sivas ekonomisinin ihracat analizi için ihracat yapan firma sayılarından hareketle toplam ihracat değeri, ihracatın sektörel ve ülkelere göre dağılımının yanı sıra ülke ekonomisi içindeki yeri dikkate alınmıştır. Sivas'ta 2006-2016 döneminde ihracat yapan firma sayısı ve ihracat değerlerine ilişkin veriler Şekil-1'de düzenlenmiştir.

\section{Şekil- 1: Sivas’ta İhracatçı Firma Sayısı ve İhracat Değeri (Bin \$)}

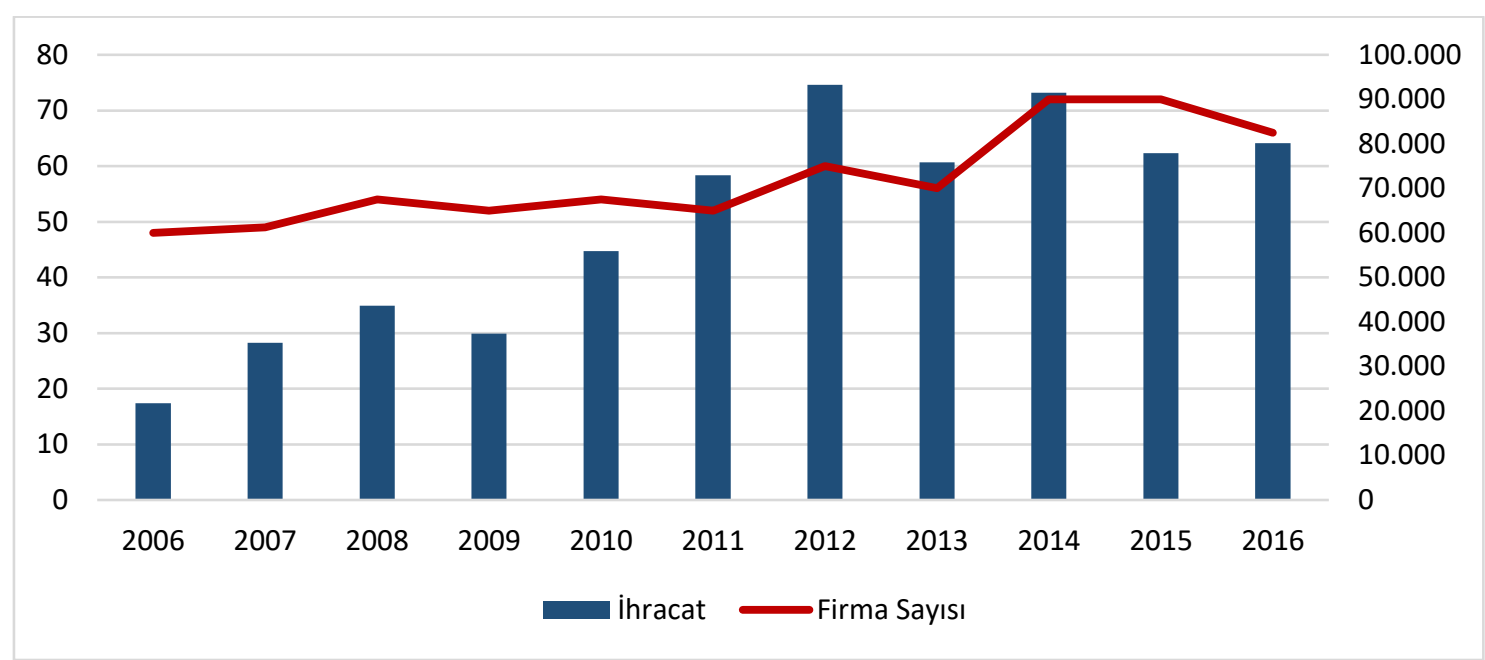

Kaynak: Ekonomi Bakanlığı, 2017.

Şekil-1 incelendiğinde 2006-2016 döneminde ihracat yapan firma sayısının arttığı y1llarda ihracatın da yükseldiği görülmektedir. 2006 yılında 48 olan ihracatçı firma sayısı, 2010 yılında 54'e, ve 2016 yılında da 60 'a yükselmiştir. Firma sayısındaki yükselişe paralel olarak Sivas ekonomisinin ihracat miktarı da artmıştır. 2006 yılında 21 milyon dolar olan ihracat değeri 2010 yılında 55 milyon dolara ve son olarak 2016 yılında 80 milyon dolara yükselmiştir. 
Tablo- 2: Sivas'ta İhracatın Sektörel Dağılımı (Bin \$)

\begin{tabular}{|l|l|l|l|l|l|}
\hline Yıllar & $\begin{array}{l}\text { Tarım ve } \\
\text { Ormancılık }\end{array}$ & $\begin{array}{l}\text { Madencilik ve } \\
\text { Taş Ocakçllı̆ } 1\end{array}$ & İmalat Sanayi & $\begin{array}{l}\text { Toptan ve } \\
\text { Perakende } \\
\text { Ticaret }\end{array}$ & Toplam İhracat \\
\hline 2006 & 9 & 4.624 & 17.068 & - & 21.701 \\
\hline 2007 & 1 & 8.669 & 26.624 & - & 35.294 \\
\hline 2008 & 106 & 10.892 & 32.683 & - & 43.682 \\
\hline 2009 & 148 & 9.770 & 27.476 & - & 37.394 \\
\hline 2010 & 615 & 22.545 & 32.732 & - & 55.891 \\
\hline 2011 & 356 & 30.886 & 41.709 & 2 & 72.953 \\
\hline 2012 & 162 & 50.495 & 42.633 & 5 & 93.295 \\
\hline 2013 & 325 & 32.019 & 43.475 & - & 75.820 \\
\hline 2014 & 293 & 33.960 & 57.240 & - & 91.493 \\
\hline 2015 & 533 & 28.246 & 49.154 & - & 77.933 \\
\hline 2016 & 1.639 & 26.363 & 52.158 & 281 & 80.161 \\
\hline
\end{tabular}

Kaynak: TÜIKK, 2017.

Tablo-2' de yer alan verilere göre, Sivas ihracatında en önemli sektör imalat sanayidir. 2006 yılında yaklaşık 21 milyon dolarlık ihracatın 17 milyon dolarlık kısmını oluşturan sektörün 2010 yılı ihracatı 32 milyon dolara, 2014 yılında ise, incelediğimiz dönem itibariyle en yüksek düzey olan 57 milyon dolara ulaşmıştır. 2016 yılında ise, toplam ihracatın \% 65'lik kısmını karşılamış ve 52 milyon dolara yükselmiştir. İmalat sanayini madencilik ve taş ocakçılığı ile tarım ve ormanc1lık sektörü izlemiştir.

Sivas'ta ihracatın ana sektörlere göre dağılımı ise Tablo-3'de düzenlenmiş̧tir.

Tablo- 3: Sivas'ta İhracatın Ana Sektörlere Göre Dağılımı (2016) (Bin \$)

\begin{tabular}{|l|l|l|l|}
\hline Sıra & Sektör & Değer & $\%$ \\
\hline 1 & Madencilik Ürünleri & 32.867 & 45 \\
\hline 2 & Makine ve Aksamları & 19.381 & 26 \\
\hline 3 & Hububat, Bakliyat, Yağlı Tohum ve Mamulleri & 8.374 & 11 \\
\hline 4 & Demir ve Demir Dışı Metaller & 2.356 & 3.2 \\
\hline 5 & İklimlendirme Sanayi & 2.054 & 2.7 \\
\hline 6 & Mobilya, Kăğıt ve Orman ürünleri & 1.973 & 2.6 \\
\hline 7 & Meyve ve Sebze Mamulleri & 1.845 & 2.5 \\
\hline 8 & Kimyevi Maddeler ve Mamuller & 1.100 & 1.5 \\
\hline 9 & Çelik & 1.023 & 1.4 \\
\hline 10 & Su Ürünleri ve Hayvansal Mamuller & 657 & 0.9 \\
\hline 11 & Otomotiv Endüstrisi & 373 & 0.5 \\
\hline 12 & Hazır Giyim Konfeksiyon & 337 & 0.4 \\
\hline 13 & Elektrik, Elektronik Hizmetler & 278 & 0.3 \\
\hline 14 & Diğer Mal ve Hizmetler & 1.092 & 2.0 \\
\hline
\end{tabular}

Kaynak: TÜIKK, 2017. 
Tablo-3'e göre 2016 yılında Sivas ekonomisinde madencilik ürünleri sanayi yaklaşık 33 milyon dolarlık değer ile ilk sırada yer almaktadır. Bu sektörü 19.3 milyon dolar ile makine ve aksamları, 8.3 milyon dolar ile hububat, bakliyat, yağlı tohum ve mamulleri, 2.3 milyon dolarla demir ve demir dışı metaller, 2 milyon dolarla iklimlendirme sanayi takip etmiştir. Bu verilere göre madencilik ürünleri toplam ihracatın $\% 45$ 'ni, Makine ve Aksamları sektörü de benzer şekilde \%26'sını, Hububat, Bakliyat, Yağlı Tohum ve Mamulleri \%11'ni ve demir ve demir dışı metaller \%3.2' sini oluşturmuştur.

Sivas'ın ihracat yaptığı on ülke Şekil -2'de yer almaktadır.

\section{Şekil- : Sivas'ın İhracatında İlk 10 Ülke}

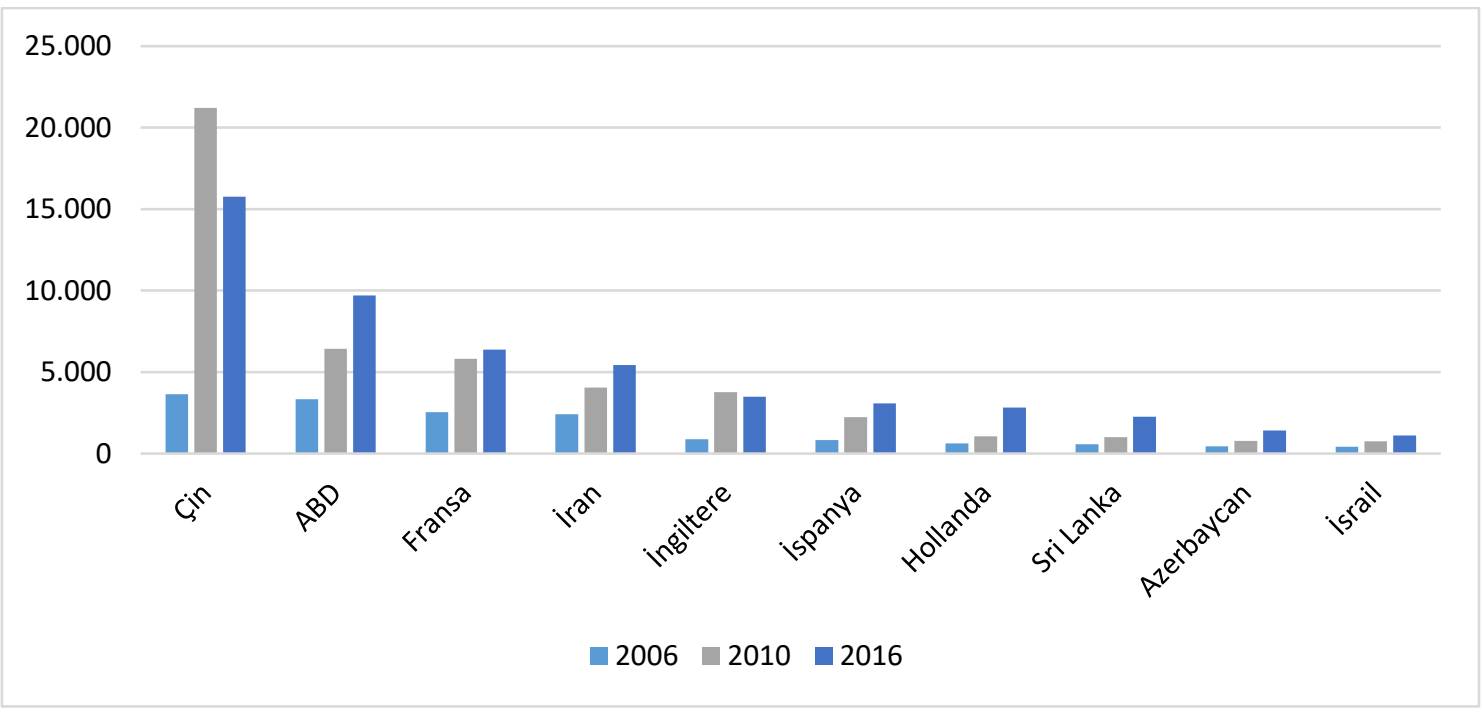

\section{Kaynak: TÜİK, 2017.}

Şekil-2'ye göre incelediğimiz dönem itibariyle Sivas'ın ihracat gerçekleştirdiği ülke sayısı \%50 artı̧̧ göstermiştir.2006 yılında 51 olan bu sayı, 2010 yılında 56'ya ve 2016 yılında 76'ya yükselmiştir. Diğer taraftan, ihracat yapılan ülke sıralaması siyasi ve ekonomik istikrarsızlıklardan dolayı değişim göstermiştir.

Sivas'ın en fazla ihracat yaptığı ilk on ülkenin gösterildiği Şekil -2'den de görüldüğü gibi, Sivas'ın 2006 yılında ihracatında ilk sırayı 3.6 milyon dolarla Çin yer alırken, bu ülkeyi sırasıyla ABD ve Fransa izlemiştir. Onuncu sırada ise 431 bin dolar ile İsrail yer almıştır.2010 yılında ise en fazla ihracat 21 milyon dolar ile yine Çin'e yapılırken, 754 bin dolar ile Irak son sırada yer almıştır. 2016 verilerine göre, Sivas ekonomisinin en fazla ihracatı 2006 ve 2010 yıllarında olduğu gibi 15.7 milyon dolar ile Çin'e gerçekleştirilmiştir. Romanya ise 1.1 milyon dolar ile onuncu sıraya yükselmiştir. Şekil 2'deki sıralamada dikkati çeken en önemli unsur, Sivas'ın ihracatının özellikle son dönemlerde ağırlıklı olarak Avrupa pazarından Orta Doğu ve Asya ülkelerine yönelmesidir.

2006-2016 döneminde Sivas ilinin ihracatı TR 7 Bölgesi'nde bulunan Aksaray, Kayseri, Kırşehir, Nevşehir, Niğde, Yozgat ve Kırıkkale şehirleriyle karşılaştırması Tablo-4'deki gibidir. 
Tablo- 4: Sivas ve Orta Anadolu İllerinin İhracatları (\$)

\begin{tabular}{|l|l|l|l|l|l|l|l|l|}
\hline Y1l & Aksaray & Kayseri & Kırşehir & Nevşehir & Niğde & Sivas & Yozgat & Kırıkkale \\
\hline 2006 & 21.946 & 751.60 & 38.33 & 19.987 & 28.719 & 21.701 & 7.339 & 1.759 \\
\hline 2007 & 40.629 & 977.54 & 77.770 & 15.498 & 29.354 & 35.294 & 19.517 & 2.851 \\
\hline 2008 & 67.699 & 1.122 .163 & 95.579 & 38.059 & 33.004 & 43.682 & 5.155 & 9.070 \\
\hline 2009 & 54.923 & 964.320 & 84.295 & 35.435 & 28.717 & 37.394 & 4.235 & 6.060 \\
\hline 2010 & 56.798 & 1.164 .317 & 143.454 & 39.165 & 53.549 & 55.891 & 11.387 & 46.943 \\
\hline 2011 & 84.405 & 1.469 .400 & 201.472 & 71.361 & 63.847 & 72.953 & 14.644 & 5.909 \\
\hline 2012 & 67.829 & 1.582 .410 & 199.812 & 49.014 & 64.756 & 93.295 & 16.405 & 5.603 \\
\hline 2013 & 73.050 & 1.765 .892 & 204.672 & 52.679 & 67.178 & 75.820 & 23.011 & 14.955 \\
\hline 2014 & 82.924 & 1.891 .139 & 211.927 & 47.822 & 66.821 & 91.493 & 14.289 & 17.291 \\
\hline 2015 & 78.409 & 1.581 .53 & 169.912 & 36.883 & 54.347 & 77.933 & 9.665 & 16.624 \\
\hline 2016 & 79.553 & 1.509 .493 & 167.059 & 50.042 & 50.839 & 80.165 & 19.886 & 19.912 \\
\hline TOP & 708.165 & 2.705 .610 & $\begin{array}{l}1.594 .25 \\
5\end{array}$ & 455.945 & 541.131 & 685.617 & 145.53 & 141.374 \\
\hline
\end{tabular}

Kaynak: TÜíK, 2017.

Tablo-4'e göre, ele alınan dönemde Sivas'ın ihracatı 2.98 kat artmıştır. Aynı dönemde söz konusu ihracat Aksaray'da 2.75 kat, Kayseri'de 4.97 kat, Kırşehir'de 2.27 kat, Nevşehir'de 3.99 kat, Niğde'de 5.64 kat, Yozgat'ta 3.69 kat ve Kırıkkale'de 8.83 kat artmıştır. Sivas bölge içerisinde ihracatı en düşük oranda artan Kırşehir ve Aksaray'dan sonra üçüncü sırada yer almaktadır.

Orta Anadolu illerinin ve Sivas'ın ihracatının ülke ihracatı ile karşılaştırılması yapıldığında Tablo-5' de yer alan sonuçlara ulaşılmıştır.

Tablo- 5: Sivas'ın Ülke İhracatındaki Payı (Bin \$)

\begin{tabular}{|l|l|l|l|l|l|}
\hline Y1llar & Türkiye & Sivas & $\begin{array}{l}\text { Sivas'1n Ülke } \\
\text { İhracatındaki Payı } \\
(\%)\end{array}$ & $\begin{array}{l}\text { Orta Anadolu } \\
\text { İllerinin } \\
\text { Toplam } \\
\text { İhracatları }\end{array}$ & $\begin{array}{l}\text { Orta Anadolu İllerinin } \\
\text { Toplam İhracatlarının } \\
\text { Ülke İhracatındaki } \\
\text { Payı (\%) }\end{array}$ \\
\hline 2006 & 85.774 .644 & 21.701 & 0.25 & 891.411 & 10.3 \\
\hline 2007 & 105.964 .665 & 35.294 & 0.33 & 1.198 .457 & 11.3 \\
\hline 2008 & 127.498 .828 & 43.682 & 0.34 & 1.414 .411 & 11.2 \\
\hline 2009 & 102.142 .613 & 37.394 & 0.36 & 1.215 .379 & 11.8 \\
\hline 2010 & 113.883 .219 & 55.891 & 0.49 & 1.571 .504 & 13.7 \\
\hline 2011 & 134.906 .869 & 72.953 & 0.54 & 1.983 .991 & 14.7 \\
\hline 2012 & 151.695 .192 & 93.295 & 0.61 & 2.079 .124 & 13.7 \\
\hline 2013 & 151.626 .709 & 75.820 & 0.50 & 2.276 .887 & 15.0 \\
\hline 2014 & 157.452 .759 & 91.493 & 0.58 & 2.423 .706 & 15.3 \\
\hline 2015 & 143.838 .871 & 77.933 & 0.54 & 2.025 .726 & 14.0 \\
\hline 2016 & 142.138 .850 & 80.161 & 0.53 & 1.976 .945 & 13.9 \\
\hline
\end{tabular}


Tablo-5'e göre Türkiye'nin toplam ihracatında Sivas'ın payı 2006 -2012 döneminde sürekli artış göstermiş ve dönem itibariyle en yüksek seviye olan \% 0.61'e 2012 yılında ulaşmıştır. Sonraki yıllarda ise dalgalı bir seyir izlemiştir. İncelediğimiz on yılda Sivas'ın Türkiye ihracatındaki payı ortalama \% 0.50 düzeyinde gerçekleşirken söz konusu oran bölge illeri için ortalama \%14 seviyesinde olduğu sonucuna ulaşılmıştır.

Tablo- 6: Türkiye'de İllerin İhracatları ve Toplam İhracattaki Payları (2016)

\begin{tabular}{|l|l|l|l|}
\hline Sira & İler & İhracat (Bin \$) & Ülke İhracatındaki Payı (\%) \\
\hline 1 & İstanbul & 57.422 .796 & 40.39 \\
\hline 2 & Bursa & 12.959 .783 & 9.11 \\
\hline 3 & Kocaeli & 10.169 .827 & 7.15 \\
\hline 4 & İzmir & 7.931 .457 & 5.58 \\
\hline 5 & Gaziantep & 6.258 .347 & 4.40 \\
\hline 6 & Ankara & 6.237 .181 & 4.38 \\
\hline 7 & Manisa & 3.772 .155 & 2.65 \\
\hline 8 & Denizli & 2.766 .607 & 1.94 \\
\hline 9 & Sakarya & 2.522 .839 & 1.77 \\
\hline 10 & Hatay & 1.745 .487 & 1.22 \\
\hline 11 & Sivas & 80.161 & 0.53 \\
\hline
\end{tabular}

Kaynak: TÜIK, 2017.

Tablo 6'ya göre, 2016 yılında İstanbul 57.4 milyar dolarlık ihracat ve \% 40.39 pay ile ülke ihracatında ilk sırada yer almıştır. İstanbul'u 12.9 milyar dolar ve \% 9.11 payla Bursa, 10.1 milyar dolar ve \% 7.15 payla Kocaeli ve 7.9 milyar dolarla İzmir takip etmiştir. İncelediğimiz bölge itibariyle Kayseri ülke ihracatında 1.5 milyar dolar ve \%1.5 payla 12 . sırada, Sivas 80.1 milyon dolar ve \% 0.53 payla 61 . sırada yer almıştır.

\section{2. İthalat Analizi}

Sivas’taki 2006-2016 yılları arasındaki ithalatçı firma sayıları ve ithalat değerleri Şekil-3 yardımıyla özetlenmiştir.

\section{Şekil-3: Sivas’ta İthalatçı Firma Sayları ve İthalat Değerleri (Bin Dolar)}

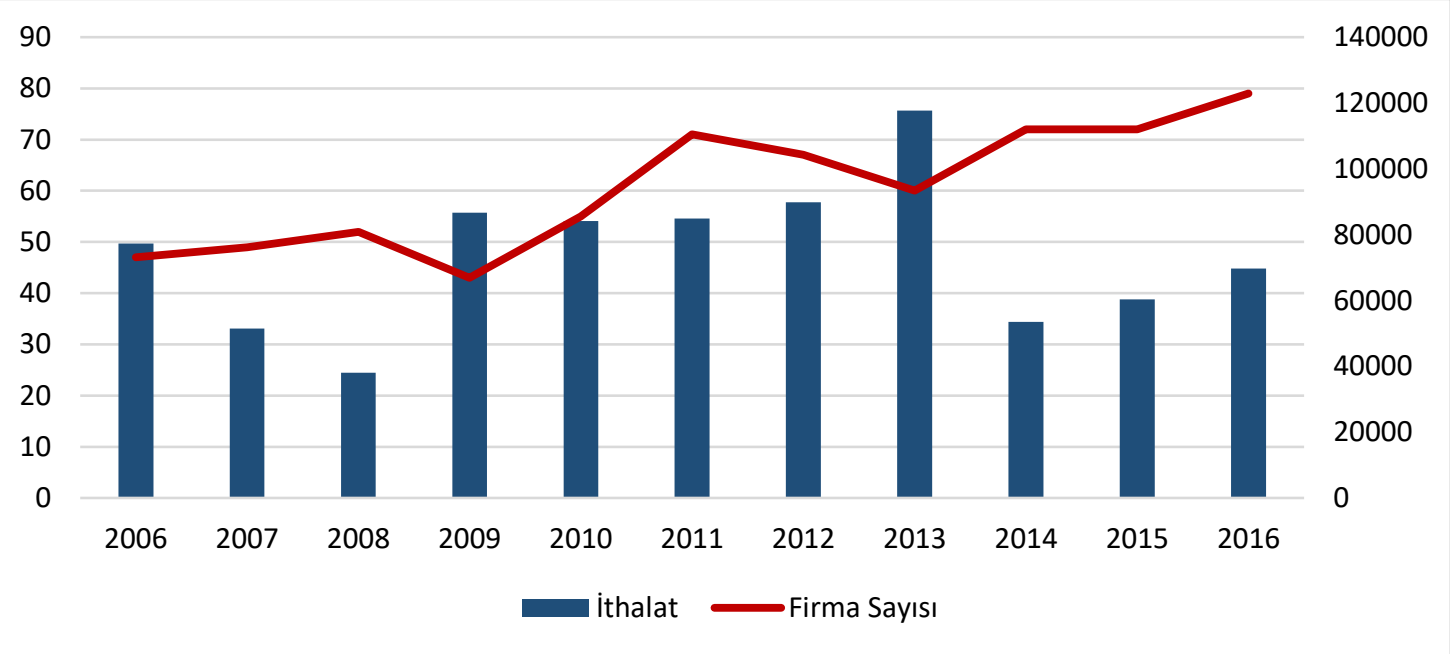

Kaynak: Ekonomi Bakanlığı, 2017

Şekil-3'e göre 2006 yılında 47 olan ithalatçı firma sayısı 2007, 2009 ve 2013 yılları hariç sürekli olarak artmış ve sayı 2010 yılında 55'e, 2012 yılında 67'ye ve 2016 yılında da 79'a yükselmiştir. Ancak ithalatçı firma sayısındaki söz konusu artışa nazaran ithalat değerindeki artış dalgalı bir seyir izlemiştir. Buna göre, 
2008 yılında 37 milyon dolara düşen ithalat değeri, 2013 yılında incelediğimiz dönem itibariyle en yüksek değer olan 117 milyon dolara yükselmiş ve son olarak 2016 y1lında 69 milyon dolar düzeyine düşmüştür.

Sivas'ta ithalatın sektörel dağılımı Tablo-7'de gösterilmektedir.

Tablo-7: Sivas'ta İthalatın Sektörel Dağılımı (Bin Dolar)

\begin{tabular}{|l|l|l|l|l|l|}
\hline Yıllar & $\begin{array}{l}\text { Tarım ve } \\
\text { Ormancılık }\end{array}$ & $\begin{array}{l}\text { Madencilik ve } \\
\text { Taş Ocakçıllı̆ı }\end{array}$ & İmalat Sanayi & $\begin{array}{l}\text { Toptan ve } \\
\text { Perakende Ticaret }\end{array}$ & Toplam İthalat \\
\hline 2006 & 36 & 11 & 23.149 & 54.098 & 77.294 \\
\hline 2007 & 88 & 15 & 42.828 & 8.518 & 51.451 \\
\hline 2008 & 3.956 & 74 & 31.873 & 2.079 & 37.985 \\
\hline 2009 & 10.317 & - & 14.006 & 62.370 & 86.692 \\
\hline 2010 & 2.301 & - & 38.255 & 43.581 & 84.137 \\
\hline 2011 & 1.732 & 38 & 35.338 & 47.745 & 84.853 \\
\hline 2012 & 2.339 & 75 & 38.387 & 49.007 & 89.808 \\
\hline 2013 & 7.425 & 5 & 52.120 & 58.123 & 117.673 \\
\hline 2014 & 11.956 & 8 & 41.578 & - & 53.542 \\
\hline 2015 & 12.937 & - & 47.432 & - & 60.369 \\
\hline 2016 & 17.339 & 25 & 52.308 & - & 69.673 \\
\hline
\end{tabular}

\section{Kaynak: TÜIK, 2017}

Tablo-7'ye göre, Sivas'ta ithalatta ilk sırada 2013 yılına kadar Toptan ve Perakende Ticaret yer almaktadır. 2006 yılında 77 milyon dolarlık ithalatın 54 milyon dolarlık kısmı Toptan ve Perakende Ticaret tarafindan gerçekleştirilmiştir. Söz konusu rakam 2010 yılında 43 milyon dolara ve 2013 yllında 58 milyon dolara yükselmiştir. Toplam ithalatın yaklaşık \%50'ni oluşturan bu sektör 2014 yılından itibaren yerini İmalat Sanayine bırakmıştır. 2014 yılında 41 milyon dolar olan İmalat Sanayi ithalatı 2016'da 52 milyon dolara çıkarak toplam ithalatın \% 74'ni oluşturmuştur. 2016 verilerini dikkate aldığımızda, İmalat Sanayini \%23'lük payla Tarım ve Ormancılık ve \%3'lük payla Madencilik ve Taş Ocakçılı̆̆ takip etmiştir.

Sivas ekonomisinin ithalatının ülkelere göre dağılımı ise Şekil-3'de yer almaktadır.

\section{Şekil-3: Sivas'ın İthalatında İlk 10 Ülke}

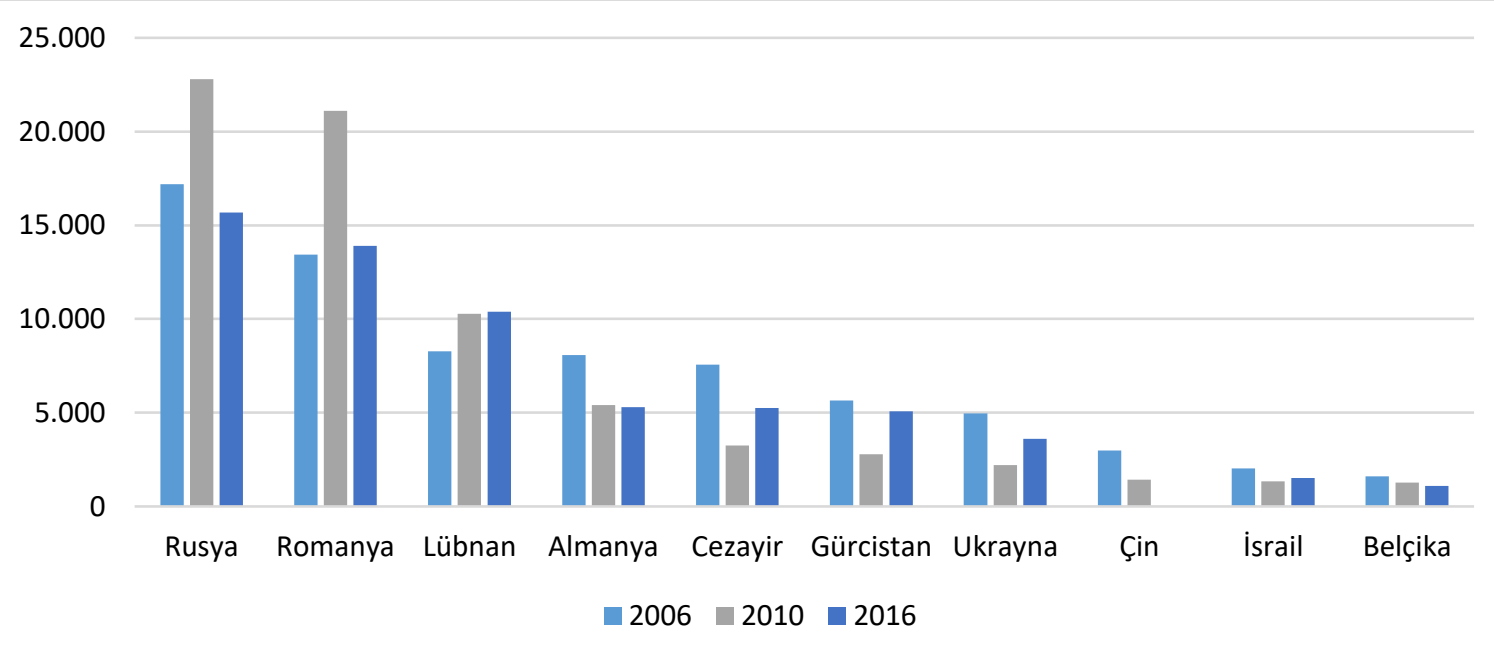

\section{Kaynak: TÜİK, 2017}

Şekil-3'e göre 2006 yılında 38 ülkeden ithalat yapılırken bu sayı 2010'da 39 yükselmiş, 2016 yılında ise 38 ülke düzeyinde gerçekleşmiştir. Rusya, Almanya ve Romanya 2006, 2010 ve 2016 yıllarında Sivas'ın ithalatında en önemli ülkelerdir. Burada dikkat çeken unsur, 2008 Krizi öncesinde ithalatın ağırlıklı olarak Avrupa piyasalarından yapıldı̆̆ı, kriz sonrasında ise tedarikçi ülkelerin Uzakdoğu ve Asya' ya kaydı̆̆ıdır. Kriz 
öncesinde beş Avrupa ülkesinden ithalat yapılırken, bu sayı 2010 yılında ikiye düşmüştür. Bu bağlamda 2006 yılında sadece Rusya, Gürcistan ve Çin tedarikçi ülke iken, 2010 y1lında bu ülkelere Gürcistan, Ukrayna, Kazakistan ve İran dâhil edilmiş, 2016 yılında ise Japonya, G.Kore ve Malezya ilk on ülke içerisinde yer almıştır.

Sivas ilinin ithalatı bölgedeki diğer şehirlerle karşılaştırıldığında Tablo-8'deki verilere ulaşılmaktadır. Bölgede ihracatta olduğu gibi ithalatta da Kayseri birinci sırada yer almaktadır. 2006-2016 döneminde Kayseri'yi toplam 1.500 milyon dolar ithalat ile Kırşehir ve 813 milyon dolar ithalat ile Sivas takip etmektedir.

Tablo-8: Sivas ve Orta Anadolu İllerinin İthalatları (Bin \$)

\begin{tabular}{|l|l|l|l|l|l|l|l|l|}
\hline Y1llar & Aksaray & Kayseri & Kırşehir & Nevşehir & Niğde & Sivas & Yozgat & Kırıkkale \\
\hline 2006 & 29.113 & 1.291 .328 & 34.343 & 11.786 & 32.357 & 77.293 & 5.992 & 2.453 \\
\hline 2007 & 49.899 & 1.291 .328 & 47.745 & 34.955 & 43.358 & 51.450 & 15.532 & 3.080 \\
\hline 2008 & 48.061 & 1.387 .750 & 99.671 & 56.460. & 32.149 & 37.984 & 18.944 & 4.121 \\
\hline 2009 & 31.483 & 1.001 .632 & 86.005 & 14.106 & 15.444 & 86.692 & 14.041 & 2.375 \\
\hline 2010 & 48.390 & 1.449 .618 & 155.695 & 18.842 & 43.027 & 84.136 & 18.488 & 13.998 \\
\hline 2011 & 66.850 & 1.724 .363 & 266.807 & 29.536 & 30.026 & 84.853 & 24.379 & 14.974 \\
\hline 2012 & 50.425 & 1.589 .200 & 211.556 & 38.030 & 20.746 & 89.808 & 18.419 & 4.707 \\
\hline 2013 & 47.050 & 1.695 .272 & 195.049 & 34.810 & 34.206 & 117.672 & 9.555 & 16.504 \\
\hline 2014 & 50.160 & 1.715 .115 & 210.719 & 35.054 & 40.683 & 53.542 & 14.745 & 13.946 \\
\hline 2015 & 62.773 & 1.471 .654 & 192.480 & 44.499 & 27.236 & 60.369 & 14.652 & 13.451 \\
\hline 2016 & 50.653 & 1.459 .758 & 211.475 & 40.473 & 37.008 & 69.673 & 32.483 & 17.447 \\
\hline
\end{tabular}

Kaynak: TÜIKK, 2017

Tablo-8'e göre 2006-2016 döneminde en yüksek ithalat artış1 \%611 ile Kırıkkale'de gerçekleşmiştir. Kırıkkale'yi \%500 artışla Kırşehir, \% 442 ile Yozgat, \%243 ile Nevşehir, \%73 ile Aksaray, \%14 ile Niğde ve \% 13 ile Kayseri takip etmektedir. Sivas ise \%9 azalışı ile bölgede önemli ithalat artışı geçekleştiremeyen tek şehir konumundadır.

\subsection{Dıș Ticaret Dengesi}

Belli dönem içinde gerçekleştirilen mal ve hizmet ithalatı ile ihracatı arasındaki değer farkı şeklinde tanımlanan diş ticaret bilançosu ekonomik rekabetin ölçülmesinde önemli bir faktördür. Tablo-9'da 2006-2016 döneminde Sivas ekonomisinin dış ticaret verileri yer almaktadır. 
Tablo-9: Sivas'ın Dış Ticaret Bilançosu (Bin \$)

\begin{tabular}{|l|l|l|l|l|}
\hline Y1lar & İhracat & İthalat & $\begin{array}{l}\text { Diş Ticaret } \\
\text { Dengesi }\end{array}$ & İhracat/İthalat \\
\hline 2006 & 21.701 & 77.294 & 55.593 & 0.28 \\
\hline 2007 & 35.294 & 51.451 & 16.157 & 0.68 \\
\hline 2008 & 43.682 & 37.985 & 5.697 & 1.14 \\
\hline 2009 & 37.394 & 86.692 & 49.298 & 0.43 \\
\hline 2010 & 55.891 & 84.137 & 28.246 & 0.66 \\
\hline 2011 & 72.953 & 84.853 & 11.900 & 0.85 \\
\hline 2012 & 93.295 & 89.808 & 3.487 & 1.03 \\
\hline 2013 & 75.820 & 117.673 & 41.853 & 0.64 \\
\hline 2014 & 91.493 & 53.542 & 37.951 & 1.70 \\
\hline 2015 & 77.933 & 60.369 & 17.564 & 1.29 \\
\hline 2016 & 80.161 & 69.673 & 10.488 & 1.15 \\
\hline
\end{tabular}

\section{Kaynak: TÜİK, 2017}

Tablo-9'daki verilere göre Sivas'in 2006 yılında yaklaşık 21 milyon dolar olan toplam ihracat1 2013, 2015 ve 2016 hariç genel anlamda artış göstermiştir. Bu bağlamda, 2010 yılında 55, 2012 yılında 93 ve 2016 yılında 80 milyon dolar düzeyinde gerçekleşmiştir. Sivas'ın toplam ithalatı da ele alınan dönemde dalgalı bir seyir izlemiştir. 2006 yılında 77 milyon dolar olan toplam ithalat, 2010 yılında 84, 2013 y1lında 117 ve 2016 yılında 69 milyon dolar olarak gerçekleşmiş̧ir. Söz konusu verilerden hareketle hesaplanan Sivas'ın dış ticaret bilançosu göz önüne alındığında, dış ticaret bilançosunun bazı yıllarda fazla, bazı yıllarda ise açık verdiği görülmektedir. Buna göre, 2008, 2012, 2014, 2015 ve 2016 yıllarında dış ticaret bilançosu fazla vermiştir. Diğer yıllarda ise açık söz konusudur. Dış ticaret bilançosunun fazla vermesi ilgili ekonominin rekabet gücünün yüksek, açık vermesi ise rekabet gücünün az olduğunun önemli bir göstergesidir.

\section{SONUÇ}

Bu çalışmada Orta Anadolu Bölgesi'nde önemli bir coğrafi konumda bulunan ve büyüme kapasitesine sahip olan Sivas'ın dış ticareti incelenmiş ve Sivas'ın da içinde bulunduğu bölgedeki illere ilişkin veriler yardımıyla bir karşılaştırma yapılmıştır. Analizlerde 2006-2016 dönemine ilişkin yıllık veriler kullanılmış olup, söz konusu veriler Ekonomi Bakanlığı, Türkiye İstatistik Kurumu (TÜİ), Sivas Ticaret ve Sanayi Odası (STO), Sivas Organize Sanayi Bölgesi Müdürlüğü (OSB) ve Gümrük ve Ticaret Bakanlığı Sivas Gümrük Müdürlügü̈’nün veri tabanlarından alınmıştır.

Analiz sonuçlarına göre, Sivas'taki Organize Sanayi Bölgesi'nde toplam 155 firma faaliyet göstermektedir. Bu firmalardan \% 18'i Fabrikasyon Metal Ürünleri İmalatında \% 16's1 Diğer İmalatlarda \% 13'lük pay da Gıda Ürünleri İmalatında yer almaktadır.

Sivas ilinin ihracat başarısı incelendiğinde; 2006 yılında 48 olan ihracatçı firma sayısı, 2016 yılında 66'ya yükselmiştir. İhracat gerçekleştiren firma sayısındaki artışa koşut olarak ihracat değeri de artmıştır. 2006 yılında 21 milyon dolar olan ihracat 2016 yılında 80 milyon dolara yükselmiştir. Bu ihracatın \% 45'lik kısmı Madencilik Ürünleri'nden oluşmaktadır. İhracat yapılan ülkeler dikkate alındığında zamanla farklılıklar ortaya çıkmış; Avrupa'da yaşanan 2008 Krizi nedeniyle ihracatın yönü Asya ve Orta Doğu'ya kaymıştır. Bu kapsamda 2016 yılı verileri dikkate alındığında Sivas'ın 76 ülkeye ihracat yaptığı belirlenmiştir. Bunlardan en fazla ihracat yapılan ülke 15 milyon dolarla Çin olmuştur. 2006-2016 döneminde bölge içerisindeki iller bazında yapılan kıyaslamalarda Sivas'ın ihracatı yaklaşık 2.98 kat artış gösterirken, söz konusu artış Kırıkkale'de 8.83, Niğde'de 5.64, Kayseri'de 4.97, Nevşehir'de 3.99, Yozgat'ta 3.69, Aksaray 2.75 ve Kırşehir'de 2.27 kat olarak gerçekleşmiştir. Ayrıca incelediğimiz dönemde Sivas'ın Türkiye ihracatındaki payı ortalama \% 0.50 düzeyinde gerçekleşirken, söz konusu oran bölge illeri için ortalama \%14 seviyesinde olduğu sonucuna ulaşılmıştır.

Sivas'ın ithalat performansı analiz edildiğinde ise, 2006 yılında ithalatçı firma sayısının 47, 2013'de 60 ve 2016 yılında 79 olduğu görülmüştür. Söz konusu firmalar tarafından gerçekleştirilen toplam ithalat da yıllar 
itibariyle inişli çıkışlı bir seyir izlemiştir.2006 yılında 77 milyon dolar olan ithalat, 2010 yılında 84 milyon dolara yükselmiş, 2016 yılında ise 69 milyon dolar düzeyine inmiştir. İthalatta ilk sıraları dönemin başında Toptan ve Perakende Ticaret alırken, sonraki süreçte İmalat Sanayi ön plana çıkmıştır. Diğer taraftan, ülke rakamları dikkate alındığında, Sivas'ın en fazla ithalatı Rusya, Almanya ve Romanya'dan gerçekleştirdiği görülmektedir. Bölgedeki iller açısından bir karşılaştırma yapıldığında ise, analiz edilen 2006-2016 döneminde en yüksek ithalat artış1 \% 611 ile Kırıkkale'de gerçekleşmiştir. Kırıkkale'yi \% 500 artışla Kırşehir, \% 442 ile Yozgat takip etmiştir. Sivas \% 9 azalışı ile bölgede ithalat artışı geçekleştiremeyen tek il konumunda kalmıştır.

Son olarak Sivas ilinin dış ticaret bilançosu incelendiğinde, 2008, 2012, 2014, 2015 ve 2016 yıllarında dış ticaret bilançosu fazla vermiştir. Diğer y1llarda ise açık söz konusudur. D1ş ticaret bilançosunun fazla vermesi, ilgili ekonominin rekabet gücünün yüksek, açık vermesi ise rekabet gücünün az olduğunun önemli bir göstergesidir. Sivas'1n bölgedeki rekabet gücünde görülen olumsuz gelişmenin en önemli nedeni gerek kamu gerekse özel sektör yatırımlarının yetersiz olmasıdır.

Çalışmanın sınırı 2006-2016 dönemi ve Sivas ili oluşturmaktadır. Bu kapsamda çalışmanın dönemi ve incelenen şehir sayısı artırılarak daha detaylı çalışmalar yapılabilir. Böylece farklı illerin dış ticaret yapıları karşılaştırmalı olarak ve çeşitli istatistiki yöntemler kullanılarak incelenebilir. 


\section{KAYNAKÇA}

Bilgin, Cevat ve Ahmet, Şahbaz, (2009) “Türkiye'de Büyüme ve İhracat Arasındaki Nedensellik İlişkisi”, Gaziantep Üniversitesi Sosyal Bilimler Dergisi 8(1), s.177-198.

Çoban, Ayşe., Orhan, Çoban., Duygu, Kurt ve M. Aykut, Uslu, (2016) "Bölgesel Rekabette Dış Ticaretin Önemi: Konya Örneği”, Sosyal Ekonomik Araştırmalar Dergisi 16 (32),s. 40-52.

Çoban, Orhan, (2003) Endüstri İktisadı ve Oyun Teorisi, Ekin Kitabevi, Bursa.

Demirhan, Erdal, (2005) "Büyüme ve İhracat Arasındaki Nedensellik İlişkisi”, Ankara Üniversitesi SBF Dergisi 60(4), s. $75-88$

Ekanayake, E.M, (1999) "Exports and Economic Growth in Asian Developing Countries: Cointegration and ErrorCorrection Models". Journal of Economic Development 24(2), s. 43-56.

Ghatak, Subrate., Chris Miller ve Utku, Utkulu, (1995) "Trade Liberalization and Endogenous Growth: Some Evidence for Turkey", Economics of Planning 28 (2-3), ss.161.

Ghirmay, Teame., Richard, Grabowski ve Subhash C. Sharma, (2001) "Exports, İnvestment, Efficiency and Economic Growth in LDC: An Empirical İnvestigation", Applied Economics 33(6), s.689-700.

Güvel, E. Alper, (2011) Ekonomik Büyüme Kuramları, Ulusların Zenginliğinin Dinamikleri, Karahan Kitabevi, Adana. Halıcıŏglu, Ferda, (2007) “A Multivariate Causality Analysis of Export and Growth for Turkey” MPRA 3565, s.1-9.

Kösekahyaoğlu, Levent ve Canan Şentürk, (2006) "İhracata Dayalı Büyüme Hipotezinin Testi: Türkiye ve Yedi Gelişen Ekonomiler Üzerine Bir İnceleme”, Süleyman Demirel Üniversitesi S.B.E. Dergisi 2(4), s. 23-45.

Kuşat, Nurdan, (2005) "Ekonomik Kalkınmanın Sürdürülebilirliğinde Liberal Dış Ticaret: 1980 Sonrası Türkiye Örneği”, Gaziantep University Journal of Social Sciences 14(1), s.39-64.

Mallick, S. Kumar, (1994) "Exports and Economics Growth", Journal of Indian School of Political Economy 6, s. 50515.

Mohsen, Bahmani-Oskooee ve İlker, Domaç, (1995) "Export Growth and Economic Growth in Turkey: Evidence from Cointegration Analysis", METU Studies in Development 22(1), s. 67-77.

ORAN (Orta Anadolu Kalkınma Ajansı), (2017) Sivas Yatırım Rehberi 2017. http://www.oran.org.tr/images/dosyalar/20170915090606_0.pdf. Erişim Tarihi: 05.07.2018.

Ramos, F . Ribeiro, (2001) "Exports, Imports, and Economic Growth in Portugal: Evidence from Causality and Cointegration Analysis" Economic Modelling 18,s. 613-623.

Saçık, S.Yapar, (2009) "Dıı̧ Ticaret Politikası ve Ekonomik Büyüme İlişkisi: Teorik Açıdan Bir İnceleme”, KMU İỉBF Dergisi 11(16), s.162-171.

Shaw, G.K, (1992) "Policy Implication of Endogenous Growth Theory". The Economic Journal. 102, s.611-621.

Şimşek, Muammer. ve Cem Kadılar, (2010) "Türkiye'de Beşeri Sermaye, İhracat ve Ekonomik Büyüme Arasındaki İlişkinin Nedensellik Analizi”, Cumhuriyet Üniversitesi İIBF Dergisi 11(1), s.115-140.

Thornton, John, (1996) "Cointegration, Causality and Export-Led Growth in Mexico", Econ. Lett. 50, s.413-416.

T.C Ekonomi Bakanlığı (2017). “İstatistik Analizler" https://www.ekonomi.gov.tr/portal/faces/home/bilgimerkezi;jsessionid=L9f81FjAqr-

r1VbC0trGF1qb_uhDhu4ctM6j_k_GmQhD0H_qee6N!452290316?_afrLoop=11014280551057307\&_afrWindo wMode $=0 \& \_$afrWindowId $=$null\&_adf.ctrl state=18zunv3ulr_1\#!\%40\%40\%3F_afrWindowId\%3Dnul1\%26_afrLoop\%3D11014280551057307\%26_afrWin dowMode\%3D0\%26_adf.ctrl-state\%3D18zunv3ulr_5. Erişim Tarihi: 10.08.2017.

TÜİK (Türkiye İstatistik Kurumu), (2017) Bölgesel Veri Tabanları http://rapory.tuik.gov.tr/20-11-2017-15:39:37185663350717134325251373743288.html Erișim Tarihi: 20.08.2018.

Türker, Munise Tuba, (2009) “İçsel Büyüme Teorilerinde İçsel Büyümenin Kaynağı Ve Uluslararası Ticaret Olgusuyla İlişkisi”, Dumlupınar Üniversitesi Sosyal Bilimler Dergisi 25, s.87-94.

Utkulu, Utku ve Durmuş Özdemir,(2004) "Does Trade Liberalization Cause a Long Run Economic Growth in Turkey?", Economics of Planning 37, s.261.

Yapraklı, Sevda, (2007)" İhracat ile Ekonomik Büyüme Arasındaki Nedensellik: Türkiye Üzerine Ekonometrik Bir Analiz", ODTÜ Gelişme Dergisi 34, s. 97-112.

Yılmaz, Ömer ve Sinan, M Temurlenk, (2005) “ Türkiye'deki İstatistik bölgelerin Kişi Başına Düssen Gelir Açısından Hiyerarşik ve Hiyerarşik Olmayan Kümeleme Analizi İle Değerlendirilmesi: 1965-2001”, Atatürk Üniversitesi, İktisadi ve İdari Bilimler Dergisi 19(2), s.75-92.

Yousif. Khalıfa Al-Yousif, (1997). "Exports and Economic Growth:Some Empirical Evidence from The Arab Gulf Countries", Applied Economics 29(6), s.693-697. 